\title{
Pengaruh Kadar SGOT SGPT dan Morfologi Hepar Tikus Putih Betina Wistar Pada Pemberian Isolat Andrografolid
}

\author{
Suryaningsih, N.M. ${ }^{1}$, Dewi, I.A.T. ${ }^{1}$, Suksmawati, N.K.A. ${ }^{1}$, Putri, N.P.R.A. ${ }^{1}$, Febrianti, N.M. ${ }^{1}$ dan \\ Warditiani, N.K. ${ }^{1}$ \\ ${ }^{1}$ Jurusan Farmasi Fakultas Matematika dan Ilmu Pengetahuan Alam Universitas Udayana
}

\author{
Korespondensi: Ni Made Suryaningsih \\ Jurusan Farmasi-Fakultas Matematika dan Ilmu Pengetahuan Alam-Universitas Udayana Jalan \\ Kampus Unud-Jimbaran, Jimbaran-Bali, Indonesia 80364 Telp/Fax: 0361-703837 Email: \\ madesurya263@gmail.com
}

\begin{abstract}
ABSTRAK
Sambiloto atau Andrographis paniculata Ness merupakan tanaman yang dimanfaatkan secara luas dalam pengobatan tradisional. Andrografolid merupakan komponen bioaktif utama dari tanaman obat sambiloto. Andrografolid mempunyai multi efek farmakologis, sehingga berpotensi besar dijadikan obat. Namun masih belum diketahui tingkat keamanaan dari penggunaan andrografolid. Tujuan dari penelitian ini adalah untuk mengetahui pengaruh pemberian isolat andrografolid dosis $18 \mathrm{mg} / \mathrm{kg} \mathrm{BB}$, $36 \mathrm{mg} / \mathrm{kg}$ BB dan $54 \mathrm{mg} / \mathrm{kg}$ BB terhadap kadar SGOT dan SGPT serta melihat histopatologi hepar tikus putih betina Wistar. Pengujian ini dilakukan selama 14 hari dengan pemberian isolat andrografolid secara peroral pada tikus putih betina wistar yang telah dibagi menjadi empat kelompok. Pengamatan kadar SGPT dan SGOT dianalisis dengan uji Anova untuk melihat ada tidaknya pengaruh pemberian isolat andrografolid. Hasil uji penelitian ini adalah tidak terdapat pengaruh pemberian isolat andrografolid dosis $18 \mathrm{mg} / \mathrm{kg} \mathrm{BB}, 36 \mathrm{mg} / \mathrm{kg}$ BB dan $54 \mathrm{mg} / \mathrm{kg}$ BB pada organ hepar serta pada kadar SGOT dan SGPT.
\end{abstract}

Kata Kunci : Sambiloto, Andrografolid, LD 50 , SGOT, SGPT, Histopatologi

\section{PENDAhUluan}

Sambiloto atau Andrographis paniculata Ness merupakan tanaman yang dimanfaatkan secara luas dalam pengobatan tradisional (Widyawati, 2007). Andrografolid merupakan komponen bioaktif utama dari tanaman obat sambiloto. Andrografolid merupakan diterpenoid lakton, berupa kristal bening dan mempunyai rasa yang sangat pahit. Andrografolid mempunyai multi efek farmakologis diantaranya, menurunkan kadar gula darah, trigliserida dan LDL, analgesik, dan imunostimulan (Nugroho et al, 2012; Suharmiati, 2001).

Andrografolid memiliki potensi besar sebagai obat, namun masih belum diketahui pengaruh pemberian isolate andrografolid terhadap kadar SGOT dan SGPT serta morfologi hepar.

Efek toksik suatu obat-obatan sering terlihat pada hepar karena hepar berperan penting dalam mendetoksifikasi senyawa yang masuk ke dalam tubuh. Hepatotoksik dapat terjadi karena terjadi penumpukan xenobiotika pada hepar yang diekskresi melalui empedu sehingga dilihat juga parameter histopatologi hepar serta kadar enzim SGOT dan SGPT pada hewan uji. Adanya peningkatan aktivitas enzim SGOT dan SGPT menjadi indikator yang kuat dan peka terhadap kelainan pada sel-sel hepar (Wulandari et al, 2007).

Penelitian bertujuan untuk mengetahui toksisitas isolat andrografolid dosis $18 \mathrm{mg} / \mathrm{kg}$ $\mathrm{BB}, 36 \mathrm{mg} / \mathrm{kg}$ BB dan $54 \mathrm{mg} / \mathrm{kg}$ BB dengan menghitung nilai $\mathrm{LD}_{50}$, kadar SGOT dan SGPT serta melihat histopatologi hepar tikus putih betina Wistar.

\section{BAHAN DAN METODE}

\subsection{Bahan}

Bahan-bahan yang digunakan pada penelitian ini yaitu daun segar sambiloto dari daerah klungkung, etanol 96\%, metanol, nheksan, etil asetat, akuades, CMC-Na.

\subsection{Alat}

Rotary evaporator (Eyela $\left.{ }^{\circledR}\right)$, oven $\left(\right.$ Binder $\left.^{\circledR}\right)$, sonikasi $\left(\right.$ Branson $\left.{ }^{\circledR}\right)$.

\subsection{Prosedur Kerja}




\subsubsection{Pembuatan Serbuk Simplisia}

Pada tahap ini dilakukan pengumpulan daun segar sambiloto, kemudian daun dicuci dan dikeringkan dalam oven. Daun sambiloto yang telah kering diserbukkan hingga halus.

\subsubsection{Pembuatan Ekstrak Terpurifikasi}

Dari Serbuk Sambiloto

$1 \mathrm{~kg}$ serbuk dimaserasi dengan etanol 96\% sebanyak 5 L selama 2 hari, kemudian disaring dan ampasnya diremaserasi 2 kali dengan 2,5 $\mathrm{L}$ etanol $96 \%$ masing-masing selama 1 hari. Maserat dikumpulkan dan diuapkan dengan vacum rotary evaporator pada suhu dibawah $50^{\circ} \mathrm{C}$ hingga diperoleh ekstrak kental. Ekstrak kental kemudian diuapkan dalam oven. Ekstrak kental yang diperoleh dicuci secara berturut-turut menggunakan nheksan, etil asetat dan air panas hingga pelarutpelarut tersebut menjadi bening.

\subsubsection{Isolasi Andrografolid}

Ekstrak terpurifikasi kental dilarutkan dengan metanol sedikit demi sedikit kemudian dipanaskan pada suhu $78^{\circ} \mathrm{C}$ sampai larut. Filtrat kemudian didinginkan perlahan. Kristal yang terbentuk dipisahkan dan dicuci dengan metanol dingin hingga bening.

\subsubsection{Pengujian Pemberian Isolat Andrografolid \\ Dilakukan aklimatisasi tikus betina}

Wistar selama 1 minggu. Hewan uji secara acak dibagi menjadi 4 kelompok yang masingmasing berisi 6 hewan uji yaitu kelompok kontrol normal dan 3 kelompok perlakuan. Kelompok kontrol normal diberikan pakan hewan uji standar dan air ad libitum. Kelompok uji 1 diberikan isolat andrografolid $18 \mathrm{mg} / \mathrm{kg}$ BB dan CMC-Na 0,1\%. Kelompok uji 2 diberikan isolat andrografolid $36 \mathrm{mg} / \mathrm{kg} \mathrm{BB}$ dan CMC-Na 0,1\%. Kelompok uji 3 diberikan isolat andrografolid $54 \mathrm{mg} / \mathrm{kg}$ BB dan CMC-Na $0,1 \%$. Sebelum pemberian isolat andrografolid, hewan uji dipuasakan selama 12 - 16 jam tetapi minum tetap diberikan. Selanjutnya makanan kembali diberikan 6 jam setelah pemberian obat uji, kemudian dilakukan pengamatan selama 14 hari. Pada hari ke-14 dilakukan autopsi dengan melakukan pemeriksaan histologis hepar serta diukur kadar SGOT dan SGPT menggunakan spektrofotometer.

\subsubsection{Pengamatan Histopatologi}

Hewan yang masih hidup sampai hari ke-14 dianastesi terlebih dahulu dengan kloroform kemudian dilakukan pembedahan. Hepar hewan uji diambil dan diawetkan dalam buffer formalin $10 \%$. Pengamatan histopatologi dilakukan dibawah mikroskop dengan menggunakan preparat hepar dengan ketebalan 5 mikron dan menggunakan pewarnaan haematoxylin. Berdasarkan hasil pengamatan dibawah mikroskop, diberikan skoring terhadap gambaran preparat hepar hewan uji sesuai yang tertera pada tabel 1 .

Tabel 1. Skoring Hasil Uji Histopatologi

\begin{tabular}{lc}
\hline \multicolumn{1}{c}{ Tingkat Perubahan } & Skor \\
\hline $\begin{array}{l}\text { Tidak ada hepatosit yang mengalami } \\
\text { degenerasi melemak }\end{array}$ & 0 \\
$<10 \%$ hepatosit yang mengalami & 1 \\
$\begin{array}{l}\text { degenerasi melemak } \\
\text { 10-30\% hepatosit yang mengalami }\end{array}$ & 2 \\
$\begin{array}{l}\text { degenerasi melemak } \\
\text { 34-66\% hepatosit yang mengalami }\end{array}$ & 3 \\
$\begin{array}{l}\text { degenerasi melemak } \\
\text { 67-100\% hepatosit yang mengalami } \\
\text { degenerasi melemak }\end{array}$ & 4 \\
\hline
\end{tabular}

2.3.6 Analisis Data

Data pengamatan kadar SGPT dan

SGOT dianalisis dengan uji Anova untuk melihat ada tidaknya pengaruh pemberian isolat andrografolid terhadap kandungan SGPT dan SGOT tikus putih betina Wistar. Kemudian dilanjutkan uji LSD apabila ternyata dari hasil uji Anova diketahui terdapat pengaruh pemberian isolat andrografolid terhadap kadar SGPT dan SGOT tikus betina. Rerata jumlah sel yang mengalami degenerasi melemak diuji normalitasnya dengan uji Saphiro-Wilk. Apabila data berdistribusi tidak normal maka dalam pengujian hipotesis berikutnya akan digunakan statistik (kruskal wallis). Pada uji statistik kruskal wallis, diperoleh nilai $(\mathrm{p}<0,05)$ yang artinya paling terdapat perbedaan jumlah sel mengalami degenerasi melemak yang bermakna antar kelompok. Analisis data dilanjutkan uji Mann Withney U-test dengan taraf kepercayaan $95 \%$.

\section{HASIL}

\subsection{Pembuatan Serbuk Simplisia}

Serbuk simplisia yang diperoleh dari daun segar sambiloto $1 \mathrm{~kg}$.

\subsection{Pembuatan Ekstrak Terpurifikasi Dari Serbuk Sambiloto \\ Ekstrak kental yang diperoleh dari ekstraksi simplisia serbuk sambiloto sebesar 96,58 gram.}


Setelah itu, dipurifikasi dengan n-heksan dan diperoleh endapan tidak larut n-heksan sebesar 86,13 gram. Endapan tersebut dipurifikasi dengan etil asetat dan diperoleh endapan tidak larut etil asetat sebesar 59,84 gram. Endapan tidak larut etil asetat dipurifikasi dengan menggunakan air panas dan diperoleh endapan tidak larut air sebesar 51,452 gram, endapan tersebut merupakan ekstrak terputifikasi sambiloto.

\subsection{Isolasi Andrografolid}

Ekstrak terpurifikasi dilarutkan dengan metanol, dipanaskan lalu didinginkan perlahan, kristal yang terbentuk dicuci dengan metanol. Diperoleh isolat andrografolid sebesar 500,20 mg.

\begin{tabular}{|c|c|c|}
\hline $\begin{array}{r}\text { Pengar } \\
\text { Androg } \\
\text { dan SGl } \\
\text { Hasil pe } \\
\text { lapat dilihat }\end{array}$ & $\begin{array}{l}\text { h Pembe } \\
\text { afolid Terhada } \\
\text { T } \\
\text { gukuran kadar } \\
\text { ada tabel. } 2 \\
\text { r SGOT dan SC }\end{array}$ & $\begin{array}{l}\text { In Isola } \\
\text { Kadar SGOT } \\
\text { OT dan SGPT }\end{array}$ \\
\hline Kelompok & $\begin{array}{c}\text { Kadar SGOT } \\
(\mathrm{U} / \mathrm{L})\end{array}$ & $\begin{array}{c}\text { Kadar SGPT } \\
(\mathrm{U} / \mathrm{L})\end{array}$ \\
\hline $\begin{array}{c}\text { Kontrol } \\
\text { normal }\end{array}$ & $94,06 \pm 18,15$ & $44,35 \pm 10,87$ \\
\hline $\begin{array}{c}18 \mathrm{mg} / \mathrm{kg} \\
\mathrm{BB}\end{array}$ & $92,03 \pm 11,33$ & $41,85 \pm 11,33$ \\
\hline $\begin{array}{c}36 \mathrm{mg} / \mathrm{kg} \\
\mathrm{BB}\end{array}$ & $89,38 \pm 16,85$ & $32,41 \pm 16,85$ \\
\hline $\begin{array}{c}54 \mathrm{mg} / \mathrm{kg} \\
\mathrm{BB}\end{array}$ & $84,78 \pm 16,39$ & $39,53 \pm 16,39$ \\
\hline
\end{tabular}

Data dalam rata-rata \pm SD

\subsection{Pengamatan Histopatologi}

Pengamatan histopatologi organ hepar pada gambar 1, menunjukkan bahwa tidak terjadi efek toksik yang ditimbulkan oleh isolat andrografolid. struktur sel dan jaringan pada organ normal dan tidak ada perubahan histopatologi. Beberapa sel mengalami degenerasi melemak, namun hal tersebut tidak terjadi pada semua organ hewan uji dalam satu kelompok hanya beberapa ekor tikus. Hasil skoring histologi hati dapat dilihat pada Tabel 3.
Tabel 3. Hasil pemeriksaan histopatologi sesuai kelompok perlakuan

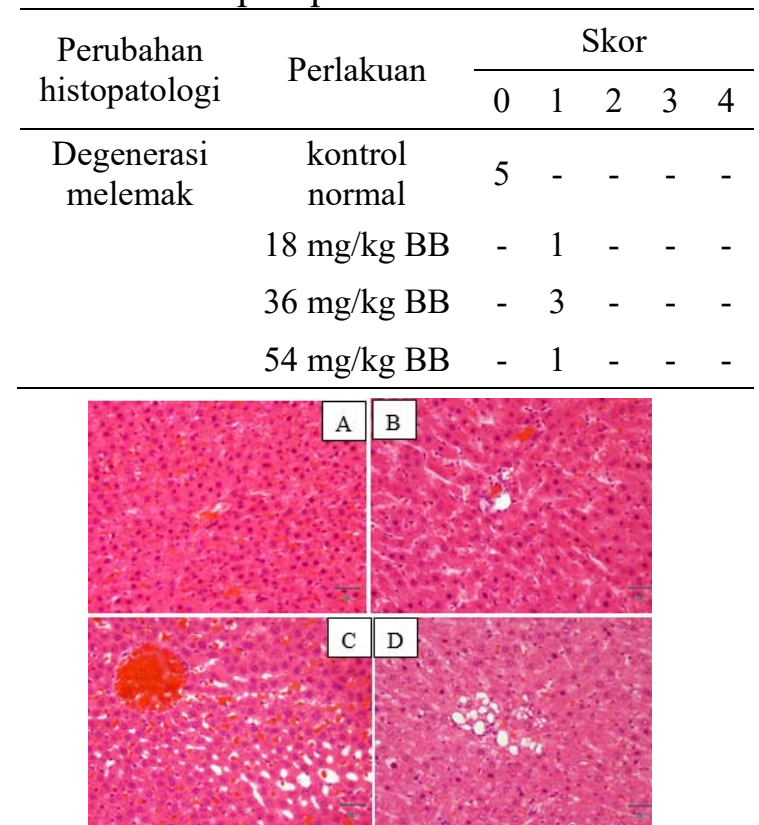

Gambar 1. A. Kelompok kontrol normal; B. Kelompok dosis $18 \mathrm{mg} / \mathrm{kg} \mathrm{BB}$; C. Kelompok dosis $36 \mathrm{mg} / \mathrm{kg} \mathrm{BB}$; D. Kelompok dosis 54 $\mathrm{mg} / \mathrm{kg} \mathrm{BB}$

\section{PEMBAHASAN}

\subsection{Pembuatan Serbuk Simplisia}

Proses penyerbukan daun sambiloto bertujuan untuk memperkecil ukuran partikel daun, sehingga diperoleh serbuk yang halus. Semakin halus serbuk simplisia, proses ekstraksi dipengaruhi oleh ukuran partikel dari serbuk simplisia. Proses ekstraksi akan lebih efektif dan efisien apabila menggunakan serbuk simplisia yang semakin halus. Akan tetapi, semakin kecil ukurann partikel simplisia akan mengakibatkan semakin rumit suatu tahapan filtrasi. Jumlah serbuk yang diperoleh dari penyerbukan $3 \mathrm{~kg}$ daun sambiloto yaitu sebanyak $1 \mathrm{~kg}$.

\subsection{Pembuatan Ekstrak Terpurifikasi Dari Serbuk Sambiloto}

Pembuatan ekstrak terpurifikasi diawali dengan proses ekstraksi dengan menggunaka metode maserasi. Proses maserasi dilakukan untuk menarik senyawa yang diinginkan dengan menggunakan pelarut yang sesuai serta dilakukan pengadukan beberapa kali dengan menggunakan suhu ruang (Ansel, 1989). Metode ini dipilih Karena merupakan metode yang sederhana, mudah dilakukan. Jumlah 
ekstrak kental yang diperoleh dari proses ekstraksi sebesar 96,58 gram. Selanjutnya dilakukan proses purifikasi esktrak dengan menggunakan n-heksan, etil-asetat, dan air panas. Proses purifikasi merupakan suatu metode untuk mendapatkan komponen bahan alam murni bebas dari komponen kimia lain yang tidak dibutuhkan. Penggunaan ekstrak terpurifikasi bertujuan untuk menghilangkan senyawa pengotor yang tidak diinginkan, meningkatkan khasiat serta memperkecil dosis pemberian kepada pengguna (Srijanto, 2012).

\subsection{Isolasi Andrografolid}

Isolasi andrografolid dilakukan dengan metode kristalisasi- rekristalisasi dengan menggunkan metanol. Pelarut metanol dapat melarutkan andrografolid pada keadaan panas, serta dapat mengendapkan andrografolid pada suhu dingin (Austin, 1996). Bobot kristral yang diperoleh sebesar 500,20 mg.

\subsection{Pengaruh Pemberian Isolat Andrografolid Terhadap Kadar SGOT dan SGPT}

Hepar merupakan pusat terjadinya proses metabolisme dalam tubuh. Salah satu indikator kerusakan sel-sel hati adalah meningkatnya kadar enzim-enzim hati dalam serum. Enzim yang digunakan untuk pengukuran kerusakan organ hepar adalah aspartate aminotransferase (AST) atau disebut juga SGOT dan alanine aminotransferase (ALT) atau SGPT. Pada keadaan normal kadar enzim SGOT maupun SGPT di dalam darah rendah karena terdapat dalam sel, tetapi jika terjadi kerusakan jaringan, maka sel akan pecah dan enzimenzim akan terurai keluar dari hepatosit masuk ke dalam sistem peredaran darah, sehingga kadarnya dalam darah akan meningkat dibandingkan dengan normal (Wahyuningsih et al., 2006).

Hasil pengukuran kadar SGPT dan SGOT dapat dilihat pada Tabel 1. Uji normalitas dan homogenitas varian data SGOT menghasilkan nilai $\mathrm{p}>0,05$ sehingga dilakukan uji Anova. Berbeda halnya dengan SGPT, uji normalitas SGPT pada dosis $54 \mathrm{mg} / \mathrm{kg} \mathrm{BB}$ menghasilkan nilai $\mathrm{P}<0.05$ sehingga data tidak terdistribusi normal maka dilakukan uji non parametrik dengan uji Kruskal-Wallis. Hasil uji Anova pada SGOT diperoleh nilai $\mathrm{p}>0,05$ yang artinya tidak ada perbedaan bermakna antara hewan uji kelompok uji dengan kontrol. Sedangkan hasil uji KruskalWallis pada SGPT juga diperoleh nilai $p>$ 0,05 yang artinya tidak ada perbedaan bermakna antara hewan uji kelompok uji dengan kontrol.

\subsection{Pengamatan Histopatologi}

Hasil pemeriksaan histopatologi dan analisis statistik uji Kruskall-Wallis pada penelitian uji toksisitas akut oral $\left(\mathrm{LD}_{50}\right)$ isolat andrografolid menunjukkan tidak ada perubahan yang signifikan $(\mathrm{P}>0,05)$. Pada kelompok kontrol normal tidak ditemukan adanya degenerasi melemak. Sedangkan pada kelompok perlakuan yang diberikan isolat andrografolid ditemukan adanya degenerasi melemak. Namun, tidak terjadi pada semua organ hewan uji dalam satu kelompok hanya beberapa ekor tikus. Degenerasi melemak merupakan akumulasi lemak dalam sitoplasma (Utami et al., 2017).

\section{KESIMPULAN}

Hasil uji penelitian ini adalah tidak terdapat pengaruh pemberian isolat andrografolid dosis $18 \mathrm{mg} / \mathrm{kg} \mathrm{BB}, 36 \mathrm{mg} / \mathrm{kg}$ BB dan $54 \mathrm{mg} / \mathrm{kg}$ BB pada organ hepar serta pada kadar SGOT dan SGPT.

\section{UCAPAN TERIMA KASIH}

Penulis mengucapkan terima kasih kepada semua pihak yang telah membantu penelitian ini.

\section{DAFTAR PUSTAKA}

Ansel, H.C. 1989. Pengatar Bentuk Sediaan Farmasi. Edisi 4. Jakarta: UI Press.

Austin, GT (1986), Schrwev's Chemical Proses Industries, N.J. : McGraw-Hill.

Assagaf, F., A. Wullur, dan A. Yudistira. 2013. Uji Toksisitas Akut (Lethal Dose 50) Ekstrak Etanol Daun Gedi Merah (Abelmoschus Manihot L.) Terhadap Tikus Putih Jantan Galur Wistar (Rattus Norvegicus L.). 
Pharmacon Jurnal Ilmiah Farmasi

- Unsrat. 2(1): 23-27.

BPOM. 2014. Peraturan Kepala Badan Pengawas Obat dan Makanan Republik Indonesia Nomor 7 Tahun 2014 Tentang Pedoman Uji Toksisitas Nonklinik Secara In Vivo. Jakarta: Badan Pengawasan Obat dan Makanan RI.

Farisi, S. A., A. Munawir, dan Z. Febianti. 2015. Uji Toksisitas Akut Ekstrak Buah Bruguiera Gymnorrhiza Pada Tikus (Rattus Norvegicus). EJurnal Pustaka Kesehatan. 3(2). pp: 230-233.

Harmita dan M. Radji. 2008. Buku Ajar Analisis Hayati Edisi 3. Jakarta: Penerbit Buku Kedokteran EGC. Hal: 4349.

Nugroho, A. E., M. Andrie, K. Warditiani, E. Siswanto, S. Pramono, dan E. Lukitaningsih. 2012. Antidiabetic and Antihiperlipidemic Effect of Andrographis paniculata (Burm. f.) Ness and Andrographolide in Highfructosa-fat-fed Rats. Indian Journal Pharmacol. 44(3): 377381.

Ratnani, R. D., I. Hartati, Dan L. Kurniasari. 2012. Potensi Produksi Andrographolide dari Sambiloto (Andrographis Paniculata Ness) Melalui Proses Ekstraksi Hidrotropi. Momentum. 8(1): 6-10.

Suharmiati dan L. Handayani. 2001. Isolasi dan Identifikasi Andrografolida dari Herba Andrographis paniculata Ness. Media Litbang Kesehatan. 11(2): 3337.

Sundari, E. 2003. Uji Toksisitas Akut Ekstrak Etanol Sambiloto (Andrographis paniculata Ness) Pada Mencit (Skirpsi). Bandung: Universitas Kristen Maranatha.

Srijanto, B., P.O. Bunga, L. Khojayanti, E. Rismana, dan Sriningsih. 2012.
Pemurnian Ekstrak Etanol

Sambiloto (Andrographis

paniculate Ness) Dengan

Teknik Ekstraksi Cair-Cair.

Jakarta: Pusat Teknologi

Farmasi da Medika BPPT.

Utami, A. R., I K. Berata, Samsuri, I M. Merdana. 2017. Efek Pemberian Propolis terhadap Gambaran Histopatologi Hepar Tikus Putih yang diberi Parasetamol. Buletin Veteriner Udayana. Vol. 9 (1): 87 93.

Wulandari, T. M. Harini, dan S. Listyawati. 2007. Pengaruh Ekstrak Daun Sambiloto (Andrographis Paniculata) Terhadap Struktur Mikroanatomi Hepar dan Kadar Glutamat Piruvat Transaminase Serum Mencit (Mus Musculus) yang Terpapar Diazinon. Bioteknologi. 4 (2): 53-58. 